\title{
Periphyton For Biofiltration And Fish Feeding in An Integrated Multi-Trophic Aquaculture System: A Case Study in The Gulf of Aqaba
}

\author{
Lior Guttman* \\ National Center for Mari culture, Israel Oceanographic \& Limnological Research, Israel
}

*Corresponding author: Lior Guttman, National Center for Mariculture, Israel Oceanographic \& Limnological Research, Eilat, Israel

\begin{abstract}
The environmental footprint of mariculture is a major obstacle towards expansion of this agro-industry. Additional economic constraints are the high costs of effluent treatment and expensive, non-sustainable ingredients in aquafeeds. Both Ulva and periphyton reveal great potential in nitrogen removal in mariculture effluent. To overcome the relatively minor uptake of nitrate by Ulva, a periphyton-based biofilter can be used either as a stand-alone biofiltration unit or as a polishing unit in an integrated Ulvaperiphyton biofilter. The biomass produced is rich in protein and is suitable for feeding of marine fish, served fresh on the plastic net substrate or included in pelleted aquafeeds to replace fishmeal.
\end{abstract}

Keywords: Aquaculture; IMTA; Nutrient removal; Periphyton; Ulva

\section{Introduction}

Excess nutrients in aquaculture effluent increase environmental footprint and may limit the expansion of this industry. While protein content in commercial feed pellets may reach $70 \%$ of dry biomass, fish retain only about $20-30 \%$ of feed nitrogen while the remainder is released into the water as dissolved and organic N. Treatment of the dissolved toxic ammonia by bacterial nitrification is efficient but results in a nitrate-rich effluent, and subsequent denitrification has yet to limit nitrate accumulation in recirculating aquaculture systems (RAS) [1]. Moreover, in these dissimilatory metabolisms' expensive nitrogen in aquafeeds is discharged to the atmosphere as $\mathrm{N}_{2}$ upon its assimilation into edible biomass. The positive role of photosynthetic organisms in nutrient assimilation and fish nutrition has been known for years [2]. Amongst other plant- based biofilters for water purification, periphyton has been suggested as a relatively inexpensive method [3]. This microbial mat develops naturally on submerged surfaces in the presence of light and nutrients. The diverse microbiota in periphyton (primary photoautotrophs) exhibit various metabolisms for nutrient utilisation [4] Periphyton also reveals high potential in fish nutrition and may significantly reduce the use of commercial pelleted aquafeeds [5]. Currently, periphyton aquaculture is established mainly in freshwater extensive fishponds for farming of carp [6], tilapia [7], and catfish [8] The development of periphyton on artificial surfaces in the ponds is facilitated by the addition of organic fertilizers [9]. In recent years, a periphyton-based biofilter for mariculture effluent was developed and integrated in a land- based, semi-intensive, integrated multi-trophic aquaculture system (IMTA) located at the National Center for Mariculture (NCM) in the Gulf of Aqaba (Eilat, Israel). The conceptual model of this periphyton biofilter (Figure 1) was innovative, as instead of co-colture of periphyton and fish in the same pond, the periphyton biofilter was separated from the primary fish culture. This spatial separation is similar to other biofilters in IMTA with extractive seaweeds of Ulva sp. [10] and Gracilaria sp. [11] and allowed examination of periphyton performance under various conditions with minimal interference (e.g., grazing of the produced biomass). A later development included the combination of a downstream periphyton biofilter with an upstream Ulva biofilter. The potential of the periphytic biomass in feeding of common marine cultured fish, the omnivorous marbled spinefoot (Siganus rivulatus) and carnivorous sea bream (Sparus aurata), was also examined. This manuscript presents primary results from the case study of periphyton in IMTA. 


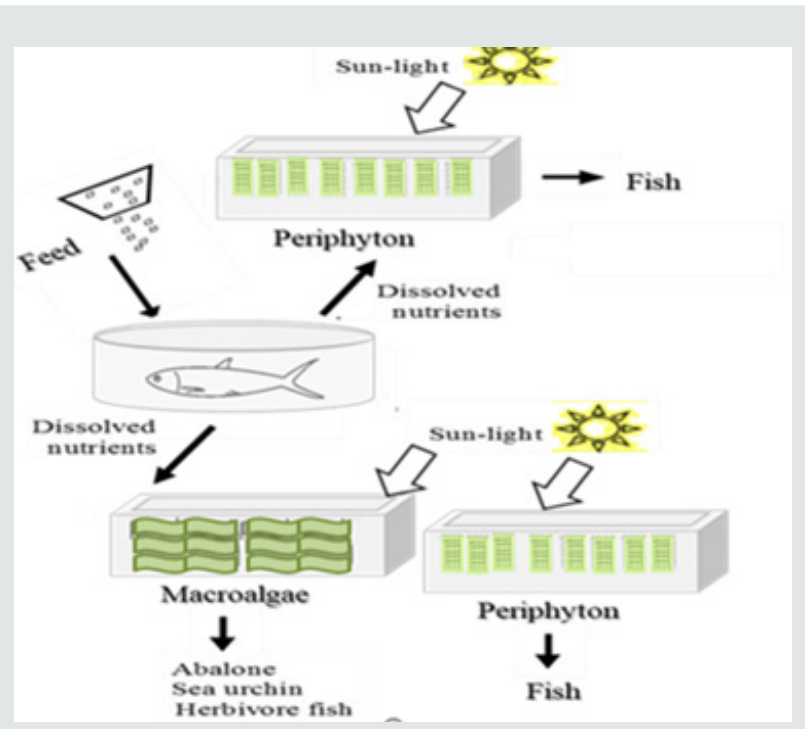

Figure 1: A diagram of periphyton in IMTA systems. Periphyton was integrated in IMTA either as sole biofilters or in combination with macroalgae (Ulva fasciata) for biofiltration of fishponds effluent and for feeding marine fish.

\section{Marine Periphyton Biofilter for Mariculture Efflu- ent}

As a sub-class of photosynthetic-based biofilters, periphyton is capable of removing inorganic nutrients from aquaculture waste with minimal aeration costs. The separation of the periphyton biofilter from primary culture units allowed the study of periphyton performance and characteristics under various conditions, towards improving biomass production and its capacity to remove nutrients. The nutrient uptake capacity of freshwater periphyton was studied previously [12] but knowledge was still required for marine periphyton. For this purpose, a marine periphyton biofiltration system was established at NCM. The periphyton system, as described elsewhere [13], comprised 12 tanks that were fed with nutrient-enriched effluent of a semi-intensive mullet production system. Biomass development in these biofilters occurs naturally on the submerged artificial plastic nets, requiring no prior inoculation. The production rate of periphyton is rapid during summer, reaching specific growth rate of $27 \% \mathrm{~d}^{-1}$, or $4 \mathrm{~g}$ ash-free dry weight (AFDW) $\mathrm{m}^{-2} \mathrm{~d}^{-1}$, and slower in other seasons of the year, up to only $7.5 \% \mathrm{~d}^{-1}$ in winter. While in traditional aquaculture ponds substrate density for periphyton development is at a 1:1 ratio to pond surface area [14], separating the periphyton biofilter allows doubling and even tripling of biomass production yields by increasing substrate density respectively [15]. Hence, if the aim is production of periphyton as edible biomass, such a management tool is highly recommended. Ammonia removal by periphyton (as total ammonium nitrogen TAN) is efficient and rapid, up to rate of $3.8 \mathrm{~g} \mathrm{TAN} \mathrm{m}^{-2} \mathrm{~d}^{-1}$, but highly affected by both biomass yield and effluent retention time in the biofilter. According to an empirical model [16] it can be estimated that in order to remove $70 \%$ of TAN in fishpond effluent at a daily rate of $1.4 \mathrm{~g} \mathrm{TAN} \mathrm{m}^{-2} \mathrm{~d}^{-1}$, a rapid streaming of nutrients is required when biomass yield is relatively high (for $\sim 100 \mathrm{~g}$ AFDW biomass at a retention time of only $1 \mathrm{~h}$ ). Such efficiency can also be achieved when biomass yield is only a third $(\sim 30 \mathrm{~g}$ AFDW $)$, for example, in the first week of periphyton development, but it requires a five-fold slower streaming of nutrients.

\section{The Combination of Seaweed Ulva Spp and Periph- yton for Mariculture Effluent}

Although dissolved ammonia is the main catabolic product of fish culture, formation of nitrate $\left(\mathrm{NO}_{3}-\mathrm{N}\right)$ by microbial activity (i.e., nitrification) may lead to relatively similar proportions of these $\mathrm{N}$ forms in effluent. Discharge of nitrate in effluent can damage sensitive coastal ecosystems via eutrophication (Howarth and Marino, 2006). In RAS, rapid nitrification leads to accumulation of nitrate (van Rijn, 1996) which harms fish growth and feed intake [16], even in systems with a denitrification treatment (van Rijn, 2013, 1996). Moreover, denitrification is dependent on the availability of organic carbon which, in some cases, is added artificially to the denitrification compartment in the form of methanol, starch, etc. In most seaweeds, ammonia uptake is more rapid than that of the oxidized $\mathrm{N}$ forms of nitrate and nitrite $\left(\mathrm{NO}_{2}-\mathrm{N}\right)$. Metabolism of the latter requires energy investment [17] for activation of the endogenic enzymes nitrate- and nitrite reductase which reduce the oxidized $\mathrm{N}$ forms to ammonia toward assimilation. Thus, removal of $\mathrm{NO}_{3}-\mathrm{N}$ by seaweeds will occur only when ammonia is nearly depleted (Syrett, 1981). Previous studies at NCM confirmed neglible uptake of $\mathrm{NO}_{3}-\mathrm{N}$ by Ulva lactuca when fed with fishpond effluent comprising both TAN and $\mathrm{NO}_{3}{ }^{-} \mathrm{N}$ (Neori, 1996). In contrast, autotrophic and heterotrophic organisms in periphyton enable metabolization of nitrogen inits various organic and inorganic forms. Nitrification, denitrification and annamox have been reported in periphyton [18]. In order to improve effluent biofiltration by means of total $\mathrm{N}$ removal, a novel integrated two-step biofilter with Ulva and periphyton was designed at NCM. Similar to a previous twostep biofilter with only Ulva sp. in both stages (Neori, 1996), the modified system integrated the periphyton biofilter downstream with an Ulva fasciata biofilter upstream. The Ulva would remove much of the ammonia in fishpond effluent, followed by polishing 
of the TAN-depleted but nitrate-rich effluents from this biofilter by the downstream periphyton. Such a combination is also expected to reduce costs of effluent treatment by not requiring aeration in the periphyton unit. The combination of Ulva and periphyton resulted in higher removal of both nitrogen and phosphorus as compared to their removal by a single unit comprising only Ulva or periphyton, and also when compared to a combined Ulva-Ulva biofilter. Overall, $76 \%$ of the nitrogen in effluent $97 \%$ of the ammonia and $67 \%$ of the nitrate) can be removed by the combination of Ulva and periphyton, with daily uptake rate of nearly $2 \mathrm{~g} \mathrm{Nm}^{-2} \mathrm{~d}^{-1}$ [19]. In contrast to Ulva, periphyton does not show $\mathrm{N}$ preference, exhibiting flexible shifts between TAN and $\mathrm{NO}_{3}{ }^{-} \mathrm{N}$ metabolism. Moreover, rapid and efficient removal of $\mathrm{NO}_{3}-\mathrm{N}$ by periphyton (up to $1.4 \mathrm{~g} \mathrm{NO}_{3}-\mathrm{Nm}^{-2} \mathrm{~d}^{-1}$ or removal of $63 \%$ of $\mathrm{NO}_{3}^{-} \mathrm{N}$ ) may occur in TAN-rich effluent ten-fold higher than that required for Ulva's transfer to $\mathrm{NO}_{3}-\mathrm{N}$ metabolism [20]. Since the specific uptake rate of TAN (in $\mathrm{N} \mathrm{gram}^{-1} \mathrm{DW} \mathrm{d}^{-1}$ ) by periphyton is relatively similar to that of Ulva and much faster in the case of $\mathrm{NO}_{3}{ }^{-} \mathrm{N}$, the combined biofiltration module is very promising for mariculture effluent. Performance can be further improved by enhancing biomass production in the periphyton unit by increasing substrate density.

\section{Biochemical and Community Composition in Pe- riphyton for Mariculture Effluent}

Periphyton is a complex community that includes representatives of various taxonomic groups from different trophic levels including detritus, micro- and macroalgae, bacteria, fungi, protozoa, zooplankton and small invertebrates [21]. Variation and dynamics in periphyton community composition are driven by various factors such as substrate submersion time [22], the type of substrate [23], seasonal changes, light intensity [24], and the available nutrients [25]. Changes in community composition also affect periphyton's biochemical composition and hence its nutritional value. For example, diatoms are rich in lipids and proteins [26] and their being served as supplemental feed on an artificial substrate improved production of post-larval shrimps [27]. The study at NCM revealed seasonal shifts in the community composition in periphyton, with cyanobacteria dominating in seasons of warmer temperature (summer and spring) and diatoms in winter and autumn. To induce diatom dominancy over that of cyanobacteria in the warmer seasons, enrichment of fishpond effluent with silica is required. Moreover, effluent enrichment with silica at a ratio of $5: 1$ between $\mathrm{Si}$ : $\mathrm{N}$ is useful in postponing the development of filamentous macroalgae on the net substrate, thereby preventing shading of the submerged periphyton by a filamentous algal mat on the water surface that would cause a crush of its biota. Silica enrichment also affects the biochemical composition of periphyton by increasing its lipid content up to tenfold higher compared to cyanobacteria-dominated periphyton. Protein level in marine periphyton from the biofilter in different seasons may vary between $29-40 \%$ of DW, with higher protein levels when cyanobacteria dominant the microbiota. Overall, protein content in marine periphyton from IMTA is somewhat higher than that measured in freshwater periphyton [28] or other studied marine periphyton [29], and comparable to measured levels in IMTA-Ulva (36\% of DW; [30]. However, the proportion of ash in periphyton may reach higher levels, up to $36 \%$ of DW, when diatoms dominant the periphyton. This may question the use of such biomass for fish feeding, due to lower digestibility. Metagenomics analyses of periphyton in mariculture effluent (using high through-put sequencing) revealed eleven bacterial phyla, with Firmicutes (53\%), Proteobacteria (17\%) and Bacterioidates (13\%) dominating the bacterial community. Periphytic autotrophs consisted of cyanobacteria, diatoms, and chlorophytes. Among eight identified members of diatoms, genus Cylindrotheca was found to be the first diatom to colonise the substrate, followed by the appearance of members of genera Navicula and Amphora. Other eukaryotes in the periphyton included Chlorophytes (from two genus taxa), Dinoflagellates, Ciliates (from two order taxa), Amoebae, Nematodes and Copepods, as well as several Fungi.

\section{Periphyton for Feeding of Cultured Marine Fish}

Periphyton is an important food of invertebrates, tadpoles, and fish in their natural aquatic habitats [31]. In aquaculture, increase of primary production in the ponds is achieved by the addition of artificial substrate for periphyton development and fertilization with organic waste prior to introduction of fish. The shift from phytoplankton-based to periphyton-based production is a primary advantage towards increasing system efficiency by means of energy and nutrient transfer. Moreover, compared to harvesting of small planktonic algae from the water column, attached periphyton can be grazed more efficiently by the cultured fish [32]. This technology has been common in tropical Africa and Asia for many years as a traditional way of enhancing fisheries in coastal lagoons without adding artificial feeds [33]. Periphyton has been used successfully to augment production of carp [34], tilapia [35] and catfish [36] in freshwater ponds. When used in fishponds for tilapia culture, commercial feed in fish diet was reduced by $40 \%$ while not harming growth performance and maintaining high water quality [37]. A few studies of herbivorous fish culture in brackish water indicated periphyton to support production of grey mullet (Mugil cephalus) and golden grey mullet [38]. Promising results in terms of growth, survival and production were also observed using periphyton in the culture of penaeid shrimp in brackish water [39]. While IMTA-Ulva lactuca and Gracilaria spp. have been indicated as nutritious feed in culture of abalone [40], sea urchins [41] and fish [42], the potential of IMTA-periphyton is to some extent unknown. To overcome this gap, a series of nutrition trials were performed at NCM. In the first trial, fresh periphyton was harvested routinely from the IMTA biofilter and served fresh, on the solid net substrate, to rabbitfish (Siganus rivulatus) fingerlings. Supplemented fresh periphyton in diet of S. rivulatus in its early stages of life (between 3-25g body weight) allowed a total discarding of fishmeal from pelleted feed as well as reducing the share of pelleted feed in fish diet by $40 \%$ (calculated as AFDW). The periphyton-supplemented diet did not affect growth performance of the fingerlings, i.e., specific growth rate (SGR), feed conversion ratio (FCR), their protein efficiency ratio (PER) or survival rates. Moreover, protein content in S. rivulatus fed with the supplementary fresh periphyton was somewhat higher than that in the pellets diet ( 51 vs. $49 \%$ of DW). In the case of 
carnivorous fish like sea bream (Sparus aurata), fingerlings are somewhat incapable of grazing periphyton directly from the solid substrate [43-55]. To overcome this, periphyton can be dried, powdered and incorporated into the pellets. This allowed reducing fishmeal content in the pellets by half, to only $125 \mathrm{~g}$ per $1 \mathrm{~kg}$ feed, when compensating with periphyton meal at the rate of $250 \mathrm{~g} \mathrm{~kg}^{-1}$ of feed. The inclusion of periphyton meal into pellets is assumed to be efficient for production of $S$. aurata over a longer period than in the case of $S$. rivulatus, as the former gained between $80111 \mathrm{~g}$ of body weight under this diet regime (starting from body weight of $\sim 10 \mathrm{~g}$ ), with SGR between $1.8-2 \% \mathrm{~d}^{-1}$, which is comparable to other trials with $S$. aurata using plant-based protein to reduce fishmeal in pelleted feeds [56-61].

\section{Acknowledgements}

The research at NCM was supported by Israel Ministry of Agriculture and Rural Development Grant No. 8940193-16 and the Bi-National Agriculture Research and Development (BARD) grant No. IS 4995 17R. The author would like to thank to all researchers, students and technicians at NCM and elsewhere for their contribution: Prof. M. Shpigel, Dr. A. Neori, Dr. A. Milstein, Prof. S. Harpaz, Prof. M. Verdegem, Dr. S.E. Boxman, A. Levy, R. Barkan, B. Sachar, M. Masasa, K. Buisman, G. Savonitto, L. Breyl, D. Ben-Ezra, V. Odinetsov, H. Chernova and A. Zalmanzon. The author would also like to thank Mikhal Ben Shaprut for making useful suggestions to the MS.

\section{References}

1. Abreu MH, Pereira R, Yarish C, Buschmann AH, Sousa Pinto I (2011) IMTA with Gracilaria vermiculophylla: Productivity and nutrient removal performance of the seaweed in a land-based pilot scale system. Aquaculture 312(1-4): 77-87.

2. Ale MT, Mikkelsen JD, Meyer AS (2011) Differential growth response of Ulva lactuca to ammonium and nitrate assimilation. J Appl Phycol 23(3): 345-351.

3. Amisah S, Adjei Boateng D, Afianu D (2008) Effects of bamboo substrate and supplementary feed on growth and production of the African catfish Clarias gariepinus. J Appl Sci Environ Manage 12(2): 25-28.

4. Anand PSS, Kohli MPS, Roy SD, Sundaray JK, Kumar S, et al. (2013) Effect of dietary supplementation of periphyton on growth performance and digestive enzyme activities in Penaeus monodon. Aquaculture 392-395: 59-68.

5. Arnold SJ, Sellars MJ, Crocos PJ, Coman GJ (2005) Response of juvenile brown tiger shrimp (Penaeus esculentus) to intensive culture conditions in a flow through tank system with three-dimensional artificial substrate. Aquaculture 246(1): 231-238.

6. Asaduzzaman M, Wahab MA, Verdegem MCJ, Benerjee S, Akter T, et al. (2009) Effects of addition of tilapia Oreochromis niloticus and substrates for periphyton developments on pond ecology and production in $\mathrm{C} / \mathrm{N}$ controlled freshwater prawn Macrobrachium rosenbergii farming systems. Aquaculture 287(3): 371-380.

7. Austin AP, Ridley Thomas CI, Lucey WP, Austin DJD (1990) Effects of nutrient enrichment on marine periphyton: Implications for abalone culture. Bot Mar 33(3): 235-240.

8. Axler RP, Reuter JE (1996) Nitrate uptake by phytoplankton and periphyton: Whole-lake enrichments and mesocosm-15N experiments in an oligotrophic lake. Limnol Oceanogr 41(4): 659-671.
9. Azim M, Verdegem MC, Khatoon H, Wahab M, van Dam A, et al. (2002) A comparison of fertilization, feeding and three periphyton substrates for increasing fish production in freshwater pond aquaculture in Bangladesh. Aquaculture 212(1-4): 227-243.

10. Azim M, Verdegem MC, Rahman M, Wahab M, van Dam A, et al. (2002) Evaluation of polyculture of Indian major carps in periphyton-based ponds. Aquaculture 213(1-4): 131-149.

11. Azim ME (2001) The potential of periphyton-based aquaculture production systems.

12. Azim ME, Asaeda T, Verdegem MCJ, van Dam AA, Beveridge MCM (2005) Periphyton structure, diversity and colonization. Periphyt Ecol Exploit Manag 15-33.

13. Azim ME, Beveridge MCM, Van Dam AA, Verdegem MCJ, van Dam A (2005) Periphyton and aquatic production: an introduction. Periphyt Ecol Exploit Manag 1-13.

14. Azim ME, Verdegem MCJ, Mantingh I, van Dam AA, Beveridge MCM (2003) Ingestion and utilization of periphyton grown on artificial substrates by Nile tilapia, Oreochromis niloticus L. Aquac. Res 34(1): 8592.

15. Azim ME, Wahab MA, Biswas PK, Asaeda T, Fujino T, et al. (2004) The effect of periphyton substrate density on production in freshwater polyculture ponds. Aquaculture 232(1): 441-453.

16. Azim ME, Wahab MA, van Dam AA, Beveridge MCM, Milstein A, et al. (2001) Optimization of fertilization rate for maximizing periphyton production on artificial substrates and the implications for periphytonbased aquaculture. Aquac Res 32: 749-760.

17. Ciric C, Ciffroy P, Charles S (2012) Use of sensitivity analysis to identify influential and non-influential parameters within an aquatic ecosystem model. Ecol Modell 246: 119-130.

18. Crab R, Avnimelech Y, Defoirdt T, Bossier P, Verstraete W (2007) Nitrogen removal techniques in aquaculture for a sustainable production. Aquaculture 270: 1-14.

19. Gordon N, Neori A, Shpigel M, Lee J, Harpaz S (2006) Effect of diatom diets on growth and survival of the abalone Haliotis discus hannai postlarvae. Aquaculture 252: 225-233.

20. Guttman L, Boxman SE, Barkan R, Neori A, Shpigel M (2018) Combinations of Ulva and periphyton as biofilters for both ammonia and nitrate in mariculture fishpond effluents. Algal Res 34: 235-243.

21. Guttman L, Neori A, Boxman SE, Barkan R, Shahar B, et al. (2019) An integrated Ulva-periphyton biofilter for mariculture effluents: Multiple nitrogen removal kinetics. Algal Res 42.

22. Hem S, Avit JLB (1994) First Results On “ Acadja-Enclos “ As An Extensive Aquaculture System (West Africa). 55(2-3): 1038-1049.

23. Howarth RW, Marino R, (2006) Nitrogen as the limiting nutrient for eutrophication in coastal marine ecosystems: Evolving views over three decades. Limnol Oceanogr 51(1-2): 364-376.

24. Jana SN, Garg SK, Patra BC (2004) Effect of periphyton on growth performance of grey mullet, Mugil cephalus (Linn.), in inland saline groundwater ponds. J Appl Ichthyol 20(2): 110-117.

25. Keshavanath P, Gangadhar B, TJ Ramesh, Jules M van Rooij, Malcolm Beveridge, et al. (2001) Use of artificial substrates to enhance production of freshwater herbivorous fish in pond culture. Aquaculture Research 32(3): 189-197.

26. Khatoon H (2006) Use of selected periphyton species to improve the water quality and shrimp postlarval production. Universiti Putra Malaysia, Malaysia.

27. Khatoon H, Yusoff FM, Banerjee S, Shariff M, Mohamed S (2007) Use of periphytic cyanobacterium and mixed diatoms coated substrate for improving water quality, survival and growth of Penaeus monodon Fabricius postlarvae. Aquaculture 27(11): 196-205. 
28. Levy A, Milstein A, Neori A, Harpaz S, Shpigel M, et al. (2017) Marine periphyton biofilters in mariculture effluents: Nutrient uptake and biomass development. Aquaculture 473: 513-520.

29. Li J, Yang X, Wang Z, Shan Y, Zheng Z, (2015) Comparison of four aquatic plant treatment systems for nutrient removal from eutrophied water. Bioresour Technol 179: 1-7.

30. Lozano NBS, Vidal AT, Martínez Llorens S, Mérida SN, Blanco JE, et al. (2007) Growth and economic profit of gilthead sea bream (Sparus aurata, L.) fed sunflower meal. Aquaculture 272: 528-534.

31. Milstein A, Levy A, Neori A, Harpaz S, Shpigel M (2018) Water quality, ecological processes and management procedures in a periphyton biofiltration system in mariculture: A statistical analysis. Aquac Res 49: 1491-1503.

32. Milstein A, Naor A, Barki A, Harpaz S (2013) Utilization of periphytic natural food as partial replacement of commercial food in organic tilapia culture-an overview. Transylvanian Rev Syst Ecol Res 15: 49-60.

33. Milstein A, Peretz Y, Harpaz S (2008) Culture of organic tilapia to market size in periphyton-based ponds with reduced feed inputs. Aquac Res 40: 55-59.

34. Milstein A, Peretz Y, Harpaz S (2008) Comparison of Periphyton Grown on Different Substrates as Food for Organic Tilapia Culture 60(4): 243 252.

35. Mulholland PJ, Rosemond AD (1992) Periphyton response to longitudinal nutrient depletion in a woodland stream: Evidence of upstream-downstream linkage. J North Am Benthol Soc 11(4): 405-419.

36. Neori A (1996) The type of N-supply (ammonia or nitrate) determines the performance of seaweed biofilters integrated with intensive fish culture. Isr J Aquac 48(1): 19-27.

37. Neori A, Cohen I, Gordin H (1991) Ulva lactuca Biofilters for Marin Fishpond Effluents. II. Growth Rate, Yield and C: N Ratio. Bot Mar 34(6): 483-489.

38. Neori A, Shpigel M, Ben Ezra D (2000) A sustainable integrated system for culture of fish, seaweed and abalone. Aquaculture 186: 279-291.

39. Perar K, Avnimelech Y, Verdegem MCJ, Kurup M, Keshavanath P (2008) Sustainable land-based aquaculture: Rational utilization of water, land and feed resources. Mediterr Aquac J 45-55.

40. Rebouças VT, Caldini NN, Cavalcante D de H, Silva FJR da, Sá MV do C e (2012) Interaction between feeding rate and area for periphyton in culture of Nile tilapia juveniles. Acta Sci Anim Sci 34(2): 161-167.

41. Richard M, Maurice JTT, Anginot A, Paticat F, Verdegem MCJCJ, et al (2010) Influence of periphyton substrates and rearing density on Liza aurata growth and production in marine nursery ponds. Aquaculture 310: 106-111.

42. Richard M, Trottier C, Verdegem MCJCJ, Hussenot JMEME (2009) Submersion time, depth, substrate type and sampling method as variation sources of marine periphyton. Aquaculture 295: 209-217.

43. Samocha TM, Fricker J, Ali AM, Shpigel M, Neori A (2015) Growth and nutrient uptake of the macroalga Gracilaria tikvahiae cultured with the shrimp Litopenaeus vannamei in an Integrated Multi Trophic Aquaculture (IMTA) system. Aquaculture 446: 263-271.

44. Sanli K, Bengtsson Palme J, Henrik Nilsson R, Kristiansson E, Rosenblad MA, et al. (2015) Metagenomic sequencing of marine periphyton: Taxonomic and functional insights into biofilm communities. Front Microbiol 6: 1192
45. Schram E, Roques JAC, Abbink W, Yokohama Y, Spanings T, et al. (2014) The impact of elevated water nitrate concentration on physiology, growth and feed intake of African catfish Clarias gariepinus (Burchell 1822). Aquac Res 45: 1499-1511.

46. Schroeder GL, Wohlfarth G, Alcon A, Halevy A, Krueger H, (1990) The dominance of algal-based food webs in fishponds receiving chemical fertilizers plus organic manures. Aquaculture 86: 219-229.

47. Shpigel M, Guttman L, Shauli L, Odintsov V, Ben Ezra D, et al. (2017) Ulva lactuca from an Integrated Multi-Trophic Aquaculture (IMTA) biofilter system as a protein supplement in gilthead seabream (Sparus aurata) diet. Aquaculture 481: 112-118.

48. Ana Carolina Calheiros, Renata Perpetuo Reis, Beatriz Castelar, Diana Negrão Cavalcanti, Valéria Laneuville Teixeira (2019) Ulva spp. as a natural source of phenylalanine and tryptophan to be used as anxiolytics in fish farming 509: 171-177.

49. Shpigel M, Shauli L, Odintsov V, Ashkenazi N, Ben Ezra D (2018) Ulva lactuca biofilter from a landbased integrated multi trophic aquaculture (IMTA) system as a sole food source for the tropical sea urchin Tripneustes gratilla elatensis. Aquaculture 496: 221-231.

50. MichéalMac Monagail, Liam. Chapter Nine - Arsenic speciation in a variety of seaweeds and associated food products Morrison.

51. Shpigel M, Shauli L, Odintsov V, Ben Ezra D, Neori A, et al. (2018) The sea urchin, Paracentrotus lividus, in an Integrated Multi-Trophic Aquaculture (IMTA) system with fish (Sparus aurata) and seaweed (Ulva lactuca) Nitrogen partitioning and proportional configurations. Aquaculture 490: 260-269.

52. Syrett PJ (1981) Nitrogen metabolism of microalgae. Physiol. bases Phytoplankt. Ecol Can Bull Fish Aquat Sci 210: 182-210.

53. Thompson FL, Abreu PC, Wasielesky W (2002) Importance of biofilm for water quality and nourishment in intensive shrimp culture. Aquaculture 203(3): 263-278

54. van Dam AA, Beveridge MCM, Azim ME, Verdegem MCJ (2002) The potential of fish production based on periphyton. Rev Fish Biol Fish 12(1): 1-31.

55. van Rijn J (2013) Waste treatment in recirculating aquaculture systems. Aquac Eng 53: 49-56.

56. Boris Delaide, Hendrik Monsees, Amit Gross, Simon Goddek (2019) Aerobic and Anaerobic Treatments for Aquaponic Sludge Reduction and Mineralisation.

57. van Rijn J (1996) The potential for integrated biological treatment systems in recirculating fish culture-A review. Aquaculture 139: 181201.

58. van Rijn J, Tal Y, Schreier HJ, (2006) Denitrification in recirculating systems: Theory and applications. Aquac. Eng 34(3): 364-376.

59. Verdegem MCJ, Eding EH, Sereti V, Munubi RN, Satacruz Reyes RA, et al. (2005) Similarities between microbial and periphytic biofilms in aquaculture systems. Periphyt Ecol Exploit Manag 191-205.

60. Wahab M, Azim M, (1999) The potential of periphyton-based culture of the native major carp calbaush, Labeo calbasu (Hamilton). Aquac 30(6): 409-419.

61. Wahab MA, Kibria MG (1994) Katha and kua fisheries-unusual fishing methods in Bangladesh. Aquac News 18: 24. 
(C) (D) This work is licensed under Creative Commons Attribution 4.0 License

To Submit Your Article Click Here: Submit Article

DOI: $10.32474 /$ OAJESS.2019.03.000171

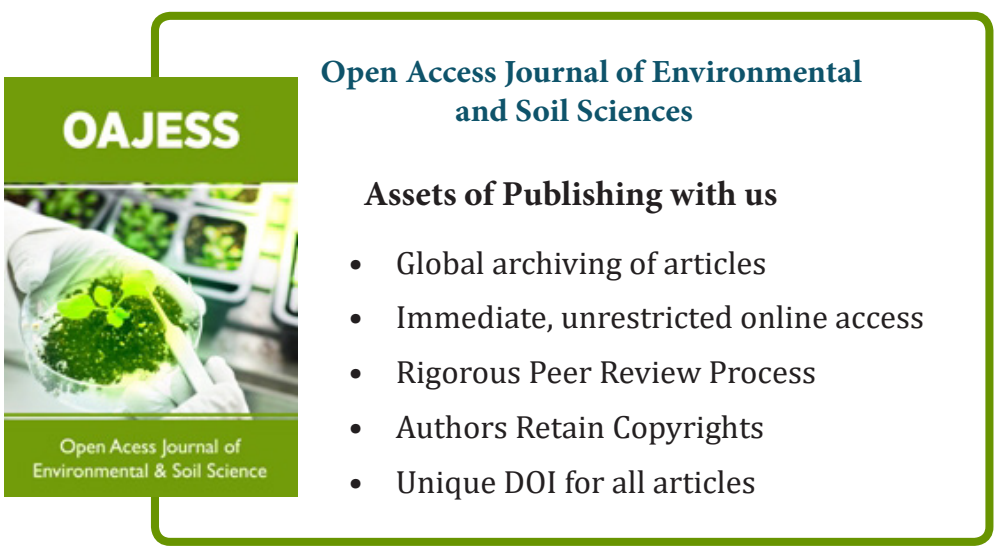

